\title{
Fine Root Morphology, Biochemistry and Litter Quality Indices of Fast- and Slow-growing Woody Species in Ethiopian Highland Forest
}

\author{
Dessie Assefa, ${ }^{1 *}$ Douglas L. Godbold, ${ }^{1}$ Beyene Belay, ${ }^{2}$ Abrham Abiyu, ${ }^{3}$ \\ and Boris Rewald ${ }^{1}$
}

\begin{abstract}
${ }^{1}$ Institute of Forest Ecology, University of Natural Resources and Life Sciences (BOKU), Peter-Jordan-Straße 82, 1190 Vienna, Austria; ${ }^{2}$ Institute of Silviculture, University of Natural Resources and Life Sciences (BOKU), Peter-Jordan-Straße 82, 1190 Vienna, Austria; ${ }^{3}$ Amhara Agricultural Research Institute, P. O. Box 527, Bahir Dar, Ethiopia
\end{abstract}

\begin{abstract}
Fine root turnover of trees is a major C input to soil. However, the quality of litter input is influenced by root morphological traits and tissue chemical composition. In this study, fine roots of ten tropical woody species were collected from an Afromontane forest in the northern highlands of Ethiopia. The fine roots were analysed for root morphological traits and tissue chemistry measured as proxy carbon fractionations. Based on stem increment, the 10 species were divided into faster- and slowergrowing species. Faster-growing species exhibited higher specific root length $\left(1362 \mathrm{~cm} \mathrm{~g}^{-1}\right)$ than slower-growing species $\left(923 \mathrm{~cm} \mathrm{~g}^{-1}\right)$. Similarly specific root area was higher in faster-growing species $\left(223 \mathrm{~cm}^{2} \mathrm{~g}^{-1}\right)$ than in slower-growing species $\left(167 \mathrm{~cm}^{2} \mathrm{~g}^{-1}\right)$. Among the carbon fractions,
\end{abstract}

the acid-insoluble fraction (AIF) was the highest $(44-51 \%)$. The carbon content, AIF, and the lignocellulose index were higher for slower-growing species. Root tissue density was lower in fastergrowing species $\left(0.33 \mathrm{~g} \mathrm{~cm}^{-3}\right)$ than slower-growing species $\left(0.40 \mathrm{~g} \mathrm{~cm}^{-3}\right)$ and showed a strong positive correlation with carbon content $\left(r^{2}=0.84\right)$ and the AIF $\left(r_{\text {pearson }}=0.93\right)$. The morphological traits of fine roots between faster- and slowergrowing species reflect the ecological strategy they employ. Slower-growing species have a higher tissue density which may reflect a greater longevity.

Key words: carbon fractions; root tissue density; specific root length; acid-insoluble fraction; carbon cost; root traits; lignin.
Received 28 February 2017; accepted 6 June 2017; published online 21 June 2017

Electronic supplementary material: The online version of this article (doi:10.1007/s10021-017-0163-7) contains supplementary material, which is available to authorized users.

Authors' Contributions: DA performed the research, analysed the data, and wrote the original draft. AA performed species identification and root sampling. BB performed tree ring analysis for species category as sloweror faster-growing species. BR and DG edited and revised the manuscript. *Corresponding author; e-mail: dessie.assefa@boku.ac.at

\section{INTRODUCTION}

The importance of fine roots for both plant and ecosystem functioning is increasingly recognized. At the same time, our understanding of root trait variation among plant species and its effects on ecological processes and biogeochemical cycling remains limited (Xia and others 2015; ValverdeBarrantes and others 2016; Weemstra and others 2016). Despite increasing information on root traits 
of plants in temperate and boreal (forest) ecosystems (Comas and others 2002; Pinno and others 2010), corresponding data on fine root characteristics of tropical tree species are rare, particularly for African ecosystems.

Parameters such as specific root length (SRL) and root tissue density (RTD) of "fine roots" ( $<2 \mathrm{~mm}$ in diameter) are key traits of a root economics spectrum. This is because they are apparently closely linked to the carbon (C) use strategy and/or resource uptake efficiency of trees (Comas and Eissenstat 2004; Birouste and others 2014; Weemstra and others 2016). From an ecological point of view, the RTD of fine roots correlates to several processes of root functioning such as: respiration rate (Makita and others 2012; Rewald and others 2014), growth rate (Birouste and others 2014), and longevity (McCormack and others 2012). Similarly, other root morphology parameters such as specific root length (SRL) have been widely used as indicators of resource use efficiency (Comas and Eissenstat 2004; Ostonen and others 2007). Interestingly, SRL and RTD are not necessary correlated across phylogenetic groups (Valverde-Barrantes and others 2016).

The chemical composition of fine root tissue may reveal further important aspects of carbon-use strategies of plants. For example, the fine root longevity of temperate tree species significantly increases with decreasing $\mathrm{C}$ to $\mathrm{N}$ ratios (McCormack and others 2012). Beyond $\mathrm{C}$ to $\mathrm{N}$ ratios, the chemical composition of fine roots regarding labile (for example, carbohydrates) and structural fractions (for example, lignin) may further enhance our understanding of (tree) root economic strategies (see Kong and others 2016). The pioneer work of Kong and colleagues, however, also again emphasizes that root trait patterns are complicated and that further studies are needed. This pertains especially to consolidate our understanding of the relations between specific $\mathrm{C}$ and $\mathrm{N}$ fractions and morphological parameters, and to improve our trait interpretations regarding (tree) fine root economic spectra. In particular, the information needed to link morphological and chemical root traits to plant growth strategies (for example, fast or slow aboveground growth) (Comas and others 2002; Comas and Eissenstat 2004) and to trait interrelationships is lacking. Currently, evidence for correlations within root traits and between root traits and the wider plant economic spectrum is weak at best. This is probably because root system function can be optimized using a much more diverse set of traits compared to leaves (Valverde-Barrantes and others 2016; Weemstra and others 2016).
Beside their key role for plant functioning, it is increasingly recognized that fine roots also play major roles in global biogeochemical cycles, including carbon sequestration (Xia and others 2015). Plant roots account for up to $48 \%$ of annual plant litter inputs (Freschet and others 2013) and are estimated to contribute an average of twofold more to soil organic $\mathrm{C}$ than leaf litter (Rasse and others 2005). Although root litter is a major source of soil organic matter, species-specific root decomposition rates and impacts on soil organic carbon turnover remain uncertain. The parameters that explain the largest amount of variability in root decay are abiotic environmental factors such as temperature and precipitation as well as root tissue chemistry (2001; Solly and others Solly and others 2014). The chemical compositions of roots as indicated by labile and structural fractions vary with species and largely determine the rate of decay (Couteaux and others 1995; Silver and Miya 2001; Sun and others 2013) and the quality of C input into soil systems (Rasse and others 2005). The labile and structural fractions of carbon in fine roots can be quantitatively determined by separating a series of fractions in a sequential fractionation, for example, solvent extractable, acid-soluble, and acid-insoluble fractions (Ryan and others 1990; Sun and others 2013). Solvent extraction with dichloromethane and boiling water removes extractable labile C compounds of nonpolar constituents such as fats, oils, waxes, and polar constituents such as nonstructural carbohydrates and water-soluble polyphenols. Acid hydrolysis using a two-stage digestion in 72 and $2.5 \% \mathrm{H}_{2} \mathrm{SO}_{4}$ removes structural components that are moderately degradable C compounds consisting primarily of cellulose and hemicellulose. The residual of the two-stage sulphuric acid digestion minus ash mass is considered as an acid-insoluble fraction (Sun and others 2013) that contains aromatic compounds referred to as lignin but also consisting of other highly reduced compounds such as suberin, cutin, and tannin-protein complexes, which are highly resistant to biodegradation (Preston and others 2000; Xia and others 2015).

This study was conducted on ten dominant tropical woody species of a diverse, pristine Afromontane forest of the north-central Ethiopian highland. The aim was to characterize fine root morphology, biochemistry and their interrelationships. The specific objectives were to determine (1) how fine root morphology and biochemistry vary between faster- and slower-growing woody species and (2) if or how fine root morphological traits are correlated to root biochemistry. We hypothesize 
that faster-growing species build "cheaper" roots of lower root tissue density (RTD) and that roots with a lower RTD contain less structural carbon fractions (less lignified roots). The results are discussed in the light of root economic strategies and the potential effects on root litter quality and quality of $\mathrm{C}$ input into soil systems.

\section{Materials AND Methods}

\section{Study Site}

This study was carried out at the remnant Afromontane forest of Gelawdios in the Amhara National Regional State, north-central Ethiopia. Gelawdios $\left(11^{\circ} 38^{\prime} 25^{\prime \prime} \mathrm{N}, 37^{\circ} 48^{\prime} 55^{\prime \prime} \mathrm{E}\right)$ is located east of Lake Tana at an altitude of 2466-2526 m above sea level. Although Ethiopia is located in the tropics, the climate of the study area is temperate with dry winters and warm summers (Cwb) according to the Köppen-Geiger climate classification (Peel and others 2007). The mean annual precipitation is $1220 \mathrm{~mm}$, with the main rainy season from June to September and with low-intensity precipitation from March to May (Wassie and others 2009). The distribution of rainfall largely depends upon the direction of moisture-bearing monsoon winds and altitude. The annual mean air temperature is $19^{\circ} \mathrm{C}$ (Wassie and others 2009). The soils are classified as Cambisols; edaphic characteristics are summarized in Supplementary Information Table (ST) 1. The Afromontane Gelawdios forest is a small, isolated, but pristine forest fragment ("church forest") covering about 100 ha in the otherwise almost completely deforested Ethiopian highlands (Wassie and others 2009; Aerts and others 2016).

Ten dominant, native woody species were studied: Allophylus abyssinicus (Hochst.) Radlk., Apodytes dimidiata E. Mey ex. Arn., Calpurnia aurea (Ait.) Benth., Chionanthus mildbraedii (Gilg \& Schellenb.) Stearn, Combretum collinum Fresen., Dovyalis abyssinica (A. Rich.) Warb., Ekebergia capensis (Sparm.), Maytenus arbutifolia (A. Rich.) Wilczek, Podocarpus falcatus (Thunb.) Mirb., and Teclea nobilis (Del.). The species were categorized into faster- and five slower-growing species based on the average yearly basal area increment (see Supplementary Materials Figure S1). In 2014 stem increment core samples were taken at breast height and annual ring width was analysed using a traversing micrometre (Maeglin 1979). The mean increase in stem radial area was then calculated for the period 2005-2014. In addition, we used literature data (Fichtl and Adi 1994; Katende and others 1995; Hedberg 2003;
Bekele 2007; Orwa and others 2009) and indigenous knowledge of local foresters to aid the categorization (see Supplementary Information Table 2). Because there is no definite criterion to categorize growth rate, we classified the species as slower- or faster-growing species. Species category, characteristics, and their corresponding local names are provided in ST 2 .

\section{Root Sampling}

Roots were sampled on 26-28 September 2014, corresponding to peak above-ground growth and the end of the rainy season. Intact fine root branches (diameter $<2 \mathrm{~mm}$ ) were collected from the topsoil under five randomly chosen individuals of each tree species along a transect line; the minimum distance between sampling locations under the same species was about $100 \mathrm{~m}$. In the diverse and relatively dense forest stand, fine root taxa for the species of interest were identified by carefully tracking coarse roots from the tree base (Rewald and others 2012). At each tree individual, three sample locations were selected. At each of the locations, one intact fine root branch was carefully extracted from a soil monolith (approx. $20 \mathrm{~cm} \times 10 \mathrm{~cm}$; top $20 \mathrm{~cm}$ of soil) with forceps; remaining soil on roots was carefully brushed away (Wang and others 2006). In total, fifteen root branches per species were separately placed into sealed plastic bags, kept in a cooling box/fridge (4$8^{\circ} \mathrm{C}$ ), and transported to Vienna, Austria, for subsequent root processing within 1 week after sampling, and stored at $4^{\circ} \mathrm{C}$. Moist paper towels were placed inside the plastic bags to prevent desiccation.

\section{Root Morphology}

On 20-22 October 2014, fine root branches were cleaned of residual soil particles with water before being submerged and spread out individually on an A3-sized transparent tray for scanning (Epson Expression 10000XL with transparency adapter; grey scale, $600 \mathrm{dpi})$. The PC software WinRhizo Pro 2012b (Regent Instruments Inc., Canada) was used to determine average root diameter $(\mathrm{mm})$, total root length $(\mathrm{cm})$ and root length per diameter class $(\mathrm{cm})$, total root surface area $\left(\mathrm{cm}^{2}\right)$, and total root volume $\left(\mathrm{cm}^{3}\right)$ of the whole root system. Twenty diameter classes $(0-2 \mathrm{~mm})$ with a class width of $0.1 \mathrm{~mm}$ each were set. Subsequently, samples were dried $\left(70^{\circ} \mathrm{C}\right.$, to constant mass) and weighed to an accuracy of $\pm 0.1 \mathrm{mg}$. The following fine root traits were calculated: specific root area (SRA; $\mathrm{cm}^{2} \mathrm{~g}^{-1}$ ), specific root length (SRL; $\mathrm{m} \mathrm{g}^{-1}$ ), and root tissue density (RTD; $\mathrm{g} \mathrm{cm}^{-3}$ ). Since root branches had 
different sizes, the value of a given length per diameter class was normalized using total root length, yielding a proportion of relative diameter class length (rDCL; Zobel and others 2007).

\section{Root Biochemistry and Construction Costs}

Oven-dry root samples of each species were pooled, due to the very limited dry mass available, and ground to powder (Fritsch Pulverisette 5, IdarOberstein, Germany). Three technical replicates per species were analysed for total $\mathrm{C}$ and $\mathrm{N}$ contents using a CN analyser (TruSpec CNS; LECO, St. Joseph, USA). Three other subsamples per species were analysed for carbon fractions using procedures adapted from Ryan and others (1990), Sun and others (2013) and Kong and others (2016). Root carbon fractions, including nonpolar extractives (fats, oil, wax), polar extractives (carbohydrates, polyphenols), acid-soluble structural components (cellulose, hemicellulose), acid-insoluble structural components (mainly lignin, suberin), and ash were assessed using a series of digestions (Ryan and others 1990).

Extractives were determined using a two-stage solvent extraction. Nonpolar fractions (NPE) were extracted from $1 \mathrm{~g}$ material with $75 \mathrm{ml}$ dichloromethane according to Sluiter and others (2005). The sample was sonicated for $30 \mathrm{~min}$ and the supernatant was centrifuged at $1050 \mathrm{~g}$ (gravitational force) for $30 \mathrm{~min}$ and decanted to a dried, pre-weighed flask. The residues were oven-dried at $60^{\circ} \mathrm{C}$ overnight to remove the residual solvent (Sluiter and others 2005), and polar fractions (PE) were extracted using hot water. Seventy-five millilitres of deionized water was added in a flask containing the residue, boiled under reflux for $3 \mathrm{~h}$, and allowed to cool. After centrifugation at $1050 \mathrm{~g}$ for $30 \mathrm{~min}$, the supernatant was decanted into clean tubes and evaporated at $60^{\circ} \mathrm{C}$ until constant weight. The residues remaining in the tubes were weighed. The two extractions removed both polar and nonpolar extractives, considered readily decomposable, leaving highly cross-linked cell wall components in the residue (Ryan and others 1990; Xia and others 2015). The sum of polar (PE) and nonpolar (NPE) extractives is named "solvent extractives" (SE) and the remaining residue "cell wall fraction". Thus, the extractive fraction is the difference between the initial weight and the weight of the cell wall fraction plus ash (Ryan and others 1990; Xia and others 2015).

The cell wall fraction was subsequently divided into acid-soluble and acid-insoluble fractions. The acid-soluble fraction (ASF), dominated by polysaccharides, was extracted using a two-stage digestion with sulphuric acid (Ryan and others 1990). Oven-dried residues $\left(60^{\circ} \mathrm{C}\right.$, to constant mass) were transferred to a test tube, and $3 \mathrm{ml}$ of $72 \%(\mathrm{w} / \mathrm{W}) \mathrm{H}_{2} \mathrm{SO}_{4}$ was added and stirred. The test tubes were placed in a water bath $\left(30^{\circ} \mathrm{C}, 3 \mathrm{~h}\right)$ and periodically stirred. Afterwards, the samples were transferred to $250 \mathrm{ml}$ Pyrex bottles (with Teflonlined screw caps) by using $84 \mathrm{ml}$ of distilled water, resulting in a $2.5 \%$ acid solution. The sealed bottles were then autoclaved $\left(121^{\circ} \mathrm{C}, \mathrm{l} \mathrm{h}\right)$. After cooling, the solutions were decanted and evaporated at $60^{\circ} \mathrm{C}$ to constant mass. This acid-soluble fraction (ASF) consists of hydrolyzed carbohydrates. The residue of the two-stage sulphuric acid digestion minus the ash mass was used to determine the acid-insoluble fraction (AIF) containing structural components (lignin). The ash content of the residues (dried at $105^{\circ} \mathrm{C}, 24 \mathrm{~h}$ ) was determined in pre-weighed, oven-dried crucibles placed in a muffle furnace at $575^{\circ} \mathrm{C}$ for $8 \mathrm{~h}$ (until no black residue remained). After ignition, the crucible + ash was cooled in a desiccator and weighed. All root chemical fractions were expressed as ash-free dry matter (DM). Litter quality indices such as $\mathrm{C}$ to $\mathrm{N}$ and AIF to $\mathrm{N}$ ratios and the lignocellulose index were calculated. The lignocellulose index was calculated as the ratio of AIF to cell wall fraction (ASF + AIF; Xia and others 2015).

Root construction costs (CC; g glucose $\mathrm{g} \mathrm{dw}^{-1}$ ) were calculated according to Vertregt and De Vries (1987) as modified by Poorter (1994). This method is widely used on both herbaceous and woody roots (Poorter and others 2006; Vivin and others 2015). CC is derived from the $C\left(\mathrm{C}_{\mathrm{dw}}\right), \mathrm{N}\left(\mathrm{N}_{\mathrm{dw}}\right)$ and ash $\left(\mathrm{Ash}_{\mathrm{dw}}\right)$ contents of dry fine roots, expressed in $\mathrm{mg} \mathrm{g}^{-1}$ :

$$
\begin{aligned}
\mathrm{CC}= & \left(-1.041-5.077 * \mathrm{C}_{\mathrm{dw}}\right) *\left(1-\mathrm{Ash}_{\mathrm{dw}}\right) \\
& +\left(5.325 * \mathrm{~N}_{\mathrm{dw}}\right)
\end{aligned}
$$

\section{Statistical Analysis}

The rDCL was plotted against diameter class according to the best fitted equation developed by Zobel and others (2007). The biomass and morphological data were analysed by one-way ANOVA to determine the differences in means among species and functional groups. Data that did not meet the assumption of normality were $\log$ or square root transformed before analysis to reach normality. If significant differences were found, multiple comparisons were carried out based on Tukey's HSD test at $p<0.05$. The data were also analysed 
using regression analysis and Pearson's correlations for examining relationships between morphological traits and biochemical fractions. Statistical tests and analyses were performed using IBM SPSS version 21; graphs were prepared using SigmaPlot (Version 13). All data shown are mean \pm standard error (SE).

\section{Results}

\section{Root Morphology}

Morphological parameters of fine roots (average diameter, SRA, SRL, and RTD) varied significantly among the ten examined woody species of the Gelawdios forest (Table 1). Fine roots (diameter $\leq 2 \mathrm{~mm}$ ) of the ten species had average root diameters (AD) between 0.52 and $0.76 \mathrm{~mm}$, with Podocarpus falcatus, Ekebergia capensis and Teclea nobilis having significantly thicker roots. On average, slower-growing species had significantly thicker fine roots than faster-growing species; however, this finding was not consistent on a species level (Table 1). Except for the three thicker-rooted species above, most examined species had a similar fine root diameter class distribution, with the majority of root length being between 0.25 and $0.40 \mathrm{~mm}$ in diameter (Figure 1). The specific root length (SRL) showed large variation among species, ranging from $635 \mathrm{~cm} \mathrm{~g}^{-1}$ (Teclea nobilis) to $1695 \mathrm{~cm} \mathrm{~g}^{-1}$ (Calpurnia aurea) (Table 1). Specific root area (SRA) differences were analogues to SRL: faster-growing species had on average both significantly higher SRL and SRA values (Table 1). Fine roots differed also in root tissue density (RTD), with slower-growing species unanimously featuring significantly higher RTD than faster-growing species (Table 1).

\section{Root Biochemistry}

The biochemistry of fine root tissues varied considerably both between individual species and between slower- and faster-growing species groups (Table 2). For example, the least amount of the nonpolar extractive fraction (NPE; includes fatty acids and lipids) was present in Apodytes dimidiata fine roots (approx. 2\% of dry matter), the highest amounts in Dovyalis abyssinica and Maytenus arbutifolia (approx. 8\% of dry matter). All three species are faster-growing. Thus, no significant differences of NPE were found between species' groups. In contrast, the amount of polar extractives (PE; incl. sugars and phenols) was significantly greater in faster-growing species. Nonetheless, values differed considerably between individual species $(4-19 \%$ of dry matter), and the difference between groups was largely driven by the high PE concentrations in the fine roots of Calpurnia aurea and Podocarpus falcatus (both faster-growing species). Consequently, solvent extractives (SE), the sum of NPE and PE, were significantly more abundant in fine roots of fastergrowing species. The cell wall fractions in root tissues of the ten studied species ranged from 76 to $90 \%$ of the dry matter. In fine roots of all species except Apodytes dimidiata, the acid-insoluble fraction (AIF; referred to as lignin) was clearly the most abundant; Apodytes dimidiata had a slightly higher acid-soluble fraction (ASF; Table 2). The slowergrowing species had a consistently and significantly greater AIF compared to faster-growing species; the

Table 1. Morphological Traits of Fine Roots ( $\leq 2 \mathrm{~mm}$ diameter) of Ten Woody Species

\begin{tabular}{|c|c|c|c|c|}
\hline Species (groups) & Diameter (mm) & SRA $\left(\mathrm{cm}^{2} \mathrm{~g}^{-1}\right)$ & SRL $\left(\mathrm{cm} \mathrm{g}^{-1}\right)$ & $\operatorname{RTD}\left(\mathrm{g} \mathrm{cm}^{-3}\right)$ \\
\hline \multicolumn{5}{|l|}{ Faster-growing (FG) } \\
\hline Apodytes dimidiata & $0.55 \pm 0.02^{\mathrm{a}}$ & $217 \pm 8^{\mathrm{cd}}$ & $1290 \pm 78^{\mathrm{bcd}}$ & $0.34 \pm 0.01^{\mathrm{a}}$ \\
\hline Calpurnia aurea & $0.53 \pm 0.04^{\mathrm{a}}$ & $254 \pm 18^{\mathrm{d}}$ & $1695 \pm 189^{\mathrm{d}}$ & $0.32 \pm 0.01^{\mathrm{a}}$ \\
\hline Dovyalis abyssinica & $0.62 \pm 0.02^{\mathrm{ab}}$ & $201 \pm 9^{\mathrm{bcd}}$ & $1076 \pm 78^{\mathrm{abcd}}$ & $0.33 \pm 0.01^{\mathrm{a}}$ \\
\hline Maytenus arbutifolia & $0.52 \pm 0.03^{\mathrm{a}}$ & $244 \pm 14^{\mathrm{d}}$ & $1588 \pm 172^{\mathrm{cd}}$ & $0.33 \pm 0.01^{\mathrm{a}}$ \\
\hline Podocarpus falcatus & $0.76 \pm 0.07^{\mathrm{b}}$ & $200 \pm 24^{\mathrm{bcd}}$ & $1156 \pm 278^{\mathrm{abcd}}$ & $0.31 \pm 0.01^{\mathrm{a}}$ \\
\hline FG average & $0.59 \pm 0.05^{\mathrm{A}}$ & $223 \pm 11^{\mathrm{B}}$ & $1362 \pm 120^{\mathrm{B}}$ & $0.33 \pm 0.01^{\mathrm{A}}$ \\
\hline \multicolumn{5}{|l|}{ Slower-growing (SG) } \\
\hline Allophylus abyssinicus & $0.55 \pm 0.01^{\mathrm{a}}$ & $179 \pm 7^{\mathrm{abc}}$ & $1055 \pm 66^{\mathrm{abc}}$ & $0.41 \pm 0.01^{\mathrm{b}}$ \\
\hline Chionanthus mildbraedii & $0.59 \pm 0.04^{\mathrm{ab}}$ & $165 \pm 9^{a b c}$ & $946 \pm 83^{\mathrm{ab}}$ & $0.43 \pm 0.01^{\mathrm{b}}$ \\
\hline Combretum collinum & $0.53 \pm 0.02^{\mathrm{a}}$ & $199 \pm 8^{\mathrm{abcd}}$ & $1249 \pm 96^{\mathrm{abcd}}$ & $0.39 \pm 0.01^{\mathrm{b}}$ \\
\hline Ekebergia capensis & $0.74 \pm 0.05^{\mathrm{b}}$ & $149 \pm 12^{\mathrm{ab}}$ & $731 \pm 96^{\mathrm{ab}}$ & $0.39 \pm 0.01^{\mathrm{b}}$ \\
\hline Teclea nobilis & $0.75 \pm 0.03^{b}$ & $142 \pm 8^{\mathrm{a}}$ & $635 \pm 71^{a}$ & $0.39 \pm 0.01^{\mathrm{b}}$ \\
\hline SG average & $0.64 \pm 0.05^{\mathrm{B}}$ & $167 \pm 10^{\mathrm{A}}$ & $923 \pm 111^{\mathrm{A}}$ & $0.40 \pm 0.01^{\mathrm{B}}$ \\
\hline
\end{tabular}




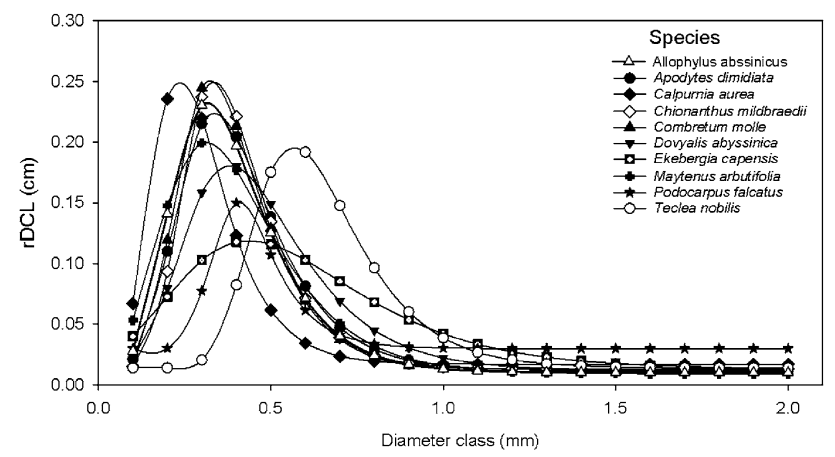

Figure 1. Nonlinear regression model of relative diameter class length distribution (rDCL; $\mathrm{cm})(n=15)$ of fine roots $\leq 2 \mathrm{~mm}$ diameter of ten tropical tree and shrub species from Gelawdios forest in the Ethiopian highland.

Table 2. Major Biochemical Fractions of Fine Roots ( $\leq 2$ diameter) of Ten Woody Species

\begin{tabular}{|c|c|c|c|c|c|c|}
\hline \multirow[t]{2}{*}{ Species (groups) } & \multicolumn{3}{|c|}{ Extractive fractions } & \multicolumn{2}{|c|}{ Cell wall fractions } & \multirow[t]{2}{*}{ Ash (\%) } \\
\hline & NPE (\%) & PE (\%) & SE $(\%)$ & ASF (\%) & AIF (\%) & \\
\hline \multicolumn{7}{|l|}{ Faster-growing (FG) } \\
\hline Apodytes dimidiata & 1.9 & 5.1 & 7.0 & 46.8 & 45.0 & 1.3 \\
\hline Calpurnia aurea & 2.8 & 13.9 & 16.7 & 37.4 & 44.2 & 1.6 \\
\hline Dovyalis abyssinica & 7.8 & 6.0 & 13.8 & 35.4 & 47.7 & 3.1 \\
\hline Maytenus arbutifolia & 7.7 & 6.5 & 14.2 & 39.9 & 44.5 & 1.4 \\
\hline Podocarpus falcatus & 7.0 & 18.6 & 25.6 & 29.6 & 43.0 & 1.8 \\
\hline FG average & $4.4 \pm 0.8^{\mathrm{A}}$ & $10.0 \pm 1.4^{\mathrm{B}}$ & $14.4 \pm 1.3^{\mathrm{B}}$ & $38.8 \pm 1.2^{\mathrm{A}}$ & $44.9 \pm 0.4^{\mathrm{A}}$ & $1.8 \pm 0.2^{\mathrm{A}}$ \\
\hline \multicolumn{7}{|l|}{ Slower-growing (SG) } \\
\hline Allophylus abyssinicus & 4.7 & 6.1 & 10.7 & 38.3 & 49.5 & 1.4 \\
\hline Chionanthus mildbraedii & 3.2 & 9.7 & 12.9 & 34.4 & 51.3 & 1.3 \\
\hline Combretum collinum & 5.2 & 3.9 & 9.2 & 39.3 & 49.1 & 2.4 \\
\hline Ekebergia capensis & 2.3 & 5.3 & 7.6 & 41.9 & 49.2 & 1.3 \\
\hline Teclea nobilis & 6.5 & 7.8 & 14.3 & 34.4 & 48.6 & 2.6 \\
\hline SG average & $4.4 \pm 0.4^{\mathrm{A}}$ & $6.6 \pm 0.6^{\mathrm{A}}$ & $11.0 \pm 0.7^{\mathrm{A}}$ & $37.7 \pm 0.8^{\mathrm{A}}$ & $49.5 \pm 0.3^{\mathrm{B}}$ & $1.8^{\mathrm{a}} \pm 0.2^{\mathrm{A}}$ \\
\hline
\end{tabular}

Shown are nonpolar extractives (NPE), polar extractives (PE), solvent extractives (SE, sum of NPE and PE), acid-soluble fraction (ASF), acid-insoluble fraction (AIF) and ash content. Species are grouped into faster (FG)- and slower-growing $(S G)$ species. Different upper-case letters indicate significance differences between FG and SG group averages $\left(\right.$ mean $\pm S E ;$ Tukey, $\left.p<0.05 ; n_{\text {group }}=5\right)$. Values for individual species are averages of three technical replicates.

ASF varied widely among the fine roots of both species groups. Ash contents were 1.3-3.1\%, with differences between some species but no systematic differences between faster- and slower-growing species. The acid-soluble fraction was highly negatively correlated to SE (Table 5). The lignocellulose index, that is, the proportion of AIF among root cell wall fractions, was significantly greater in slower-growing species; however, inter-specific differences within groups were high (Table 3 ).

The carbon (C) content of fine roots ranged from approximately $44-50 \%$, whereas nitrogen (N) content ranged from 1.1 to $1.7 \%$ of dry matter (Table 3). Both $\mathrm{C}$ and $\mathrm{N}$ contents varied across species. The root $\mathrm{C}$ content was significantly greater in slower-growing species and highly positively correlated to AIF (Table 5). Among the species, the $\mathrm{C}$ to $\mathrm{N}$ ratios varied greatly, with no trend according to growth rate. Similarly, the AIF to $\mathrm{N}$ ratio, used as an indicator of litter quality, did not differ between faster- and slower-growing species in general, but significant differences between individual species were found; AIF to $\mathrm{N}$ ratios varied between 26 and 42 (Table 3).

\section{Carbon Cost of Root Production}

The calculated amount of glucose needed to produce one gram of fine root biomass varied among species (Table 4). These carbon costs were highest in Chionanthus mildbraedii ( $1.5 \mathrm{~g}$ glucose $\mathrm{g}^{-1} \mathrm{dw}$ ) and lowest in Calpurnia aurea roots (1.2 g glucose $\left.\mathrm{g}^{-1} \mathrm{dw}\right)$. The calculated amount of glucose needed to synthesize root biomass was significantly and consistently greater in slower-growing species compared to faster-growing species (Table 4).

\section{Correlation of Morphological and Biochemical of Fine Root Traits}

Pearson's correlations within and between morphological traits, biochemical fractions and $\mathrm{C}$ and $\mathrm{N}$ contents of fine roots are given in Table 5; linear 
Table 3. Litter Quality Indices of Ten Woody Species

\begin{tabular}{|c|c|c|c|c|c|}
\hline Species (groups) & $\mathrm{C} \%$ & $\mathrm{~N} \%$ & $\mathrm{C}$ to $\mathrm{N}$ ratio & AIF to $\mathrm{N}$ ratio & Lignocellulose index \\
\hline \multicolumn{6}{|l|}{ Faster-growing (FG) } \\
\hline Apodytes dimidiata & 44.8 & 1.38 & 32.6 & 32.7 & 0.49 \\
\hline Calpurnia aurea & 44.5 & 1.21 & 36.8 & 36.6 & 0.54 \\
\hline Dovyalis abyssinica & 46.3 & 1.38 & 33.7 & 34.7 & 0.57 \\
\hline Maytenus arbutifolia & 45.2 & 1.73 & 26.2 & 25.8 & 0.53 \\
\hline Podocarpus falcatus & 45.3 & 1.08 & 42.0 & 39.9 & 0.56 \\
\hline FG average & $45.2 \pm 0.24^{\mathrm{A}}$ & $1.35 \pm 0.06^{\mathrm{A}}$ & $34.3 \pm 1.4^{\mathrm{A}}$ & $33.9 \pm 1.3^{\mathrm{A}}$ & $0.54 \pm 0.01^{\mathrm{A}}$ \\
\hline \multicolumn{6}{|l|}{ Slower-growing (SG) } \\
\hline Allophylus abyssinicus & 48.2 & 1.26 & 38.3 & 39.4 & 0.56 \\
\hline Chionanthus mildbraedii & 49.9 & 1.51 & 33.0 & 33.9 & 0.60 \\
\hline Combretum collinum & 47.1 & 1.36 & 34.6 & 36.1 & 0.56 \\
\hline Ekebergia capensis & 47.5 & 1.17 & 40.4 & 41.9 & 0.54 \\
\hline Teclea nobilis & 47.1 & 1.74 & 27.1 & 28.0 & 0.59 \\
\hline SG average & $47.9 \pm 0.29^{\mathrm{B}}$ & $1.41 \mathrm{X} \pm 0.04^{\mathrm{A}}$ & $34.7 \pm 1.2^{\mathrm{A}}$ & $35.9 \pm 1.3^{\mathrm{A}}$ & $0.57 \pm 0.01^{\mathrm{B}}$ \\
\hline
\end{tabular}

Shown are carbon $(C)$ and nitrogen $(N)$ contents, and $C$ to $N$ ratio, acid-insoluble fraction $(A I F)$ to $N$ ratio and lignocellulose index. Species are grouped into faster (FG)- and slower-growing (SG) species; see Supplementary Information Table 2 for details. Lignocellulose index is the ratio of AIF to cell wall fraction. Upper-case letters indicate differences between FG and SG group averages (mean $\pm S E$; Tukey, $p<0.05 ; n_{\text {groups }}=5$ ). Values for individual species are averages of three technical replicates.

Table 4. Estimated Glucose Investment for Fine Root Biomass Production ( $\leq 2$ diameter) of Ten Woody Species

\begin{tabular}{|c|c|}
\hline Species (groups) & Carbon cost $\left(\mathrm{g}\right.$ glucose $\left.\mathrm{g}^{-1} \mathrm{dw}\right)$ \\
\hline \multicolumn{2}{|l|}{ Faster-growing (FG) } \\
\hline Apodytes dimidiata & 1.23 \\
\hline Calpurnia aurea & 1.21 \\
\hline Dovyalis abyssinica & 1.31 \\
\hline Maytenus arbutifolia & 1.25 \\
\hline Podocarpus falcatus & 1.25 \\
\hline FG average & $1.25 \pm 0.01^{\mathrm{A}}$ \\
\hline \multicolumn{2}{|l|}{ Slower-growing (SG) } \\
\hline Allophylus abyssinicus & 1.41 \\
\hline Chionanthus mildbraedii & 1.50 \\
\hline Combretum collinum & 1.35 \\
\hline Ekebergia capensis & 1.37 \\
\hline Teclea nobilis & 1.34 \\
\hline SG average & $1.39 \pm 0.02^{\mathrm{B}}$ \\
\hline
\end{tabular}

correlations of selected traits with $\mathrm{C}$ contents are shown in Figure 2A-D. Average root diameter was highly negatively correlated to SRL, and RTD was highly negatively correlated to SRA (Table 5). Among the biochemical root fractions, solvent extraction (SE) was highly negatively correlated with the acid-soluble fraction (ASF) but highly positively correlated to the polar extractive (PE) (Table 5). The acid-insoluble fraction (AIF) was strongly positively correlated with root tissue density and significantly negatively correlated with both SRL and SRA. Fine root C content was also negatively correlated to SRL/SRA. However, the C content was highly positively correlated to RTD and AIF (Table 5; Figure 2C, D). Moreover, a weak correlation between $\mathrm{C}$ contents and the lignocellulose index (Figure 2B) was found. Nitrogen content showed a positive correlation with PE (Table 5), but no correlation with other root morphological or biochemical traits, including $\mathrm{C}$ (Figure 2A). Within morphological traits, significant negative correlations were found between average diameters (AD) and SRL/SRA and between SRA and RTD; SRL and SRA were highly positively 

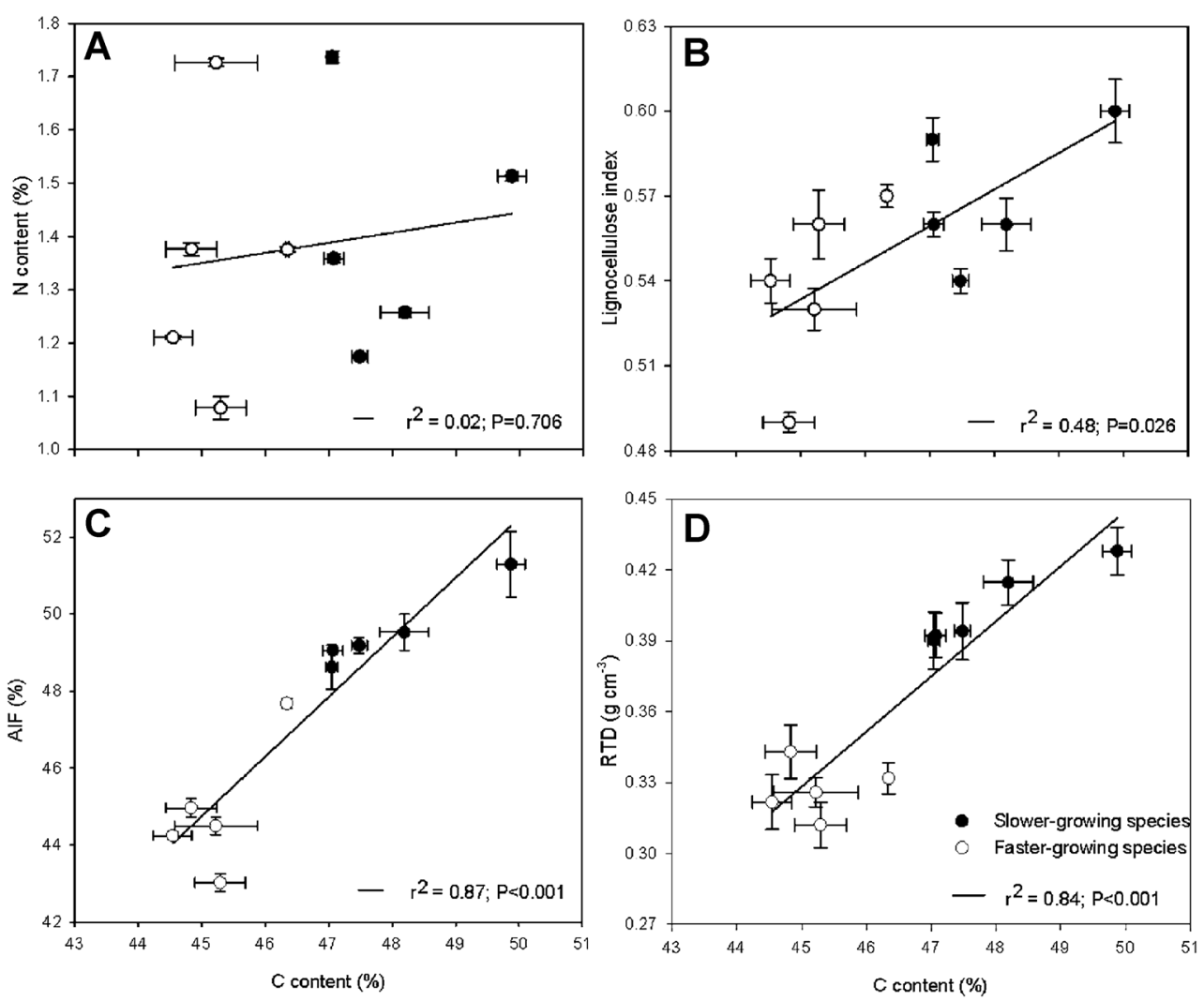

Figure 2. Linear correlations of carbon content $(\mathrm{C}, \%)$ in fine roots of five faster- and five slower-growing woody species of the Gelawdios forest, NW Ethiopia with A nitrogen content $(\mathrm{N} ; \%)$; B lignocellulose index (AIF to cell wall fraction ratio); C acid-insoluble fractions (AIF; \%); and D root tissue density (RTD; $\mathrm{g} \mathrm{cm}^{-3}$ ) (mean $\pm \mathrm{SE}$; Tukey, $p<0.05 ; n=3$ ). correlated (Table 5). All extractive fractions (NPE, $\mathrm{PE}, \mathrm{EF})$ and ASF of fine roots appeared to be unrelated to any root morphological characteristics (Table 5).

\section{Discussion}

\section{Root Morphological Traits and Growth Pattern}

Variation in root traits among different coexisting tropical tree species are poorly known, especially fine root characteristics of tropical tree species of African ecosystems. This makes the identification of plant functional traits that can be linked to ecosystem processes very interesting, especially the C sequestration potential (Rasse and others 2005; Gilbert and others 2014; Xia and others 2015). Many studies suggest that small diameter roots (mainly lower root orders) tend to have greater absorptive capacity (Rewald and others 2012; Kong and others 2014, 2016) but shorter lifespans compared to coarser fine roots (McCormack and others 2012). Such roots are also considered to play an important role in soil carbon input and nutrient cycling. The average diameters of fine roots $(0.53-$ $0.76 \mathrm{~mm}$ ) we recorded in Ethiopia are in the range reported for tree species of other tropical ecosys- tems (0.52-1.4 mm; Collins and others 2016), but are considerably larger than those frequently reported for trees in temperate forests [0.24$0.54 \mathrm{~mm} ; \mathrm{Gu}$ and others 2014)] and boreal forests (0.31-0.47; Ostonen and others 2013). For example, Pinno and others (2010) reported-for roots of Populus tremuloides in boreal forests-that $97 \%$ of the total root length is $<1 \mathrm{~mm}$ diameter. Other studies have yielded similar findings: roots $<0.5 \mathrm{~mm}$ in diameter accounted for $89 \%$ of the total root length in Prunus avium (Baddeley and Watson 2005) and 75\% for nine North American tree species (Pregitzer and others 2002). In our study, about $50 \%$ of the total fine root length was below $0.5 \mathrm{~mm}$, and more than $80 \%$ of the total length were accounted for by root segments $<1 \mathrm{~mm}$ in diameter (Figure 1; Table 1). Species such as Maytenus arbutifolia, Combretum collinum, and Allophylus abyssinicus are the thinnest (90\% of total root length $\leq 1 \mathrm{~mm}$ diameter), while Podocarpus falcatus, Ekebergia capensis, and Teclea nobilis had the thickest roots (Table 1). Overall, the vast majority of fine root length was below $1 \mathrm{~mm}$ in diameter for all species (Figure 1). It has been shown that coarser fine roots show secondary growth, as evidenced by the highest root tissue density (RTD), and have a lower specific root area (SRA) than finer roots (Silver and Miya 2001; Re- 
Table 5. Pearson's Correlation Matrix of Root Morphological and Chemical Traits

\begin{tabular}{|c|c|c|c|c|c|c|c|c|c|c|}
\hline & $\mathrm{PE}$ & SE & ASF & AIF & $\mathrm{C}$ & $\mathrm{N}$ & $\mathrm{AD}$ & SRA & SRL & RTD \\
\hline NPE & -0.42 & 0.09 & -0.31 & -0.16 & 0.03 & $0.67^{*}$ & -0.19 & 0.05 & 0.01 & -0.01 \\
\hline $\mathrm{PE}$ & & $0.89 * *$ & -0.52 & -0.55 & -0.35 & -0.33 & 0.35 & 0.23 & 0.22 & -0.46 \\
\hline SE & & & $-0.74^{*}$ & -0.51 & -0.36 & 0.00 & 0.28 & 0.28 & 0.25 & -0.51 \\
\hline ASF & & & & -0.36 & -0.28 & -0.14 & -0.35 & 0.25 & 0.24 & 0.11 \\
\hline AIF & & & & & $0.95^{* *}$ & -0.16 & 0.33 & $-0.74^{* *}$ & $-0.67^{*}$ & 0.93 ** \\
\hline $\mathrm{C}$ & & & & & & 0.13 & 0.08 & $-0.74^{*}$ & $-0.65 *$ & $0.94^{* *}$ \\
\hline $\mathrm{N}$ & & & & & & & -0.12 & 0.08 & 0.09 & 0.18 \\
\hline $\mathrm{AD}$ & & & & & & & & $-0.66^{*}$ & $-0.72 *$ & 0.01 \\
\hline SRA & & & & & & & & & 0.98 ** & $-0.73^{*}$ \\
\hline SRL & & & & & & & & & & -0.62 \\
\hline
\end{tabular}

Values are the Pearson (r) value of the 4 morphological and 6 chemical traits across 10 co-occurring woody species in the Gelawdios forest, NW Ethiopia ( $n=10)$. Significant correlations $(p<0.05)$ are indicated in bold.

NPE nonpolar extractives, PE polar extractives, SE solvent extraction, ASF acid-soluble fraction, AIF acid-insoluble fraction, SRL specific root length, SRA specific root area, $R T D$ root tissue density, $A D$ average root diameter.

${ }^{*} p<0.05 ; * * p<0.01$.

wald and others 2014). In our study, fine root diameter was negatively correlated with SRA $\left(r_{\text {pearson }}=-0.66 ; p<0.05\right)$ and SRL $\left(r_{\text {pearson }}=-\right.$ $0.72 ; p<0.05 ;$ Table 5). Basile and others (2007) also reported a similar negative correlation.

Comparing morphological traits with growth rates showed that average RTD is lower in fastergrowing species, whereas SRA and SRL are higher in slower-growing species. Some of the fastergrowing species such as Calpurnia aurea and Maytenus arbutifolia had much higher SRA and SRL than the slower-growing species Ekebergia capensis and Teclea nobilis, which exhibited the lowest SRA and SRL values (Table 1). Similar results have been reported for other species, where very fine roots of faster-growing species had much higher SRL (Pregitzer and others 1997; Basile and others 2007). Similarly, the RTD values $\left(0.31-0.41 \mathrm{~g} \mathrm{~cm}^{-3}\right)$ are in the range reported for tree species of other tropical ecosystems $\left(0.2-0.6 \mathrm{~g} \mathrm{~cm}^{-3}\right.$; Collins and others 2016) and for temperate trees (0.32-0.83: McCormack and others 2012), but they are greater than values previously found in other temperate forest ecosystems (Comas and Eissenstat 2004). Several authors have suggested that a wide variety of climate and soil conditions such as temperature, moisture, nutrient content, $\mathrm{pH}$, and physical disturbance of the soil affect fine root morphology (Pregitzer and others 2002; Ostonen and others 2007; Zobel and others 2007). In coexisting species of the same site, however, the morphological differences may reflect the species' economic spectrum and ecological strategies for resource capture under competition (Wang and others 2006; Collins and others 2016; Valverde-Barrantes and others 2016). High SRA and SRL may facilitate faster growth and more rapid acquisition of soil resources (Valverde-Barrantes and others 2016). Given the apparent species-specific differences in root morphology between coexisting species, many authors have emphasized root morphological plasticity as an important adaptation mode to variable growth conditions (Fransen and others 1999; Sorgoná and others 2007; Ostonen and others 2013; Gratani 2014). Based on the optimal foraging theory, Ostonen and others (2007) identified two main strategies of fine root adaptation to different regimes of nutrient supply: higher $\mathrm{C}$ investment to increase the fine root biomass (and root length), or changing root morphology to increase nutrient uptake efficiency through a higher specific root area. Similar ideas have been suggested by Meinen and others (2009) to explain differences in root morphology between species. In relation to the morphological parameters, SRA and SRL decreased with increasing RTD (Table 5). The negative associations of SRA and SRL with RTD suggest that the faster-growing species increase the total surface area of absorbing roots for higher nutrient use efficiency and that their roots are less expensive to construct per unit mass (Table 4). Similarly, Pregitzer and others (2002) reported that "infinitely fine" roots are the most efficient for nutrient acquisition per gram of $\mathrm{C}$ expended to construct them. In contrast, slower-growing species tended to construct more C-costly fine roots.

\section{Root Biochemistry and Carbon Cost Implications for Root Litter Quality}

The fine roots of all ten species differed with respect to concentrations of $\mathrm{C}$ and $\mathrm{N}$ as well as in chemical 
compounds. The C content ranged from $44 \%$ (Calpurnia aurea) to $50 \%$ (Chionanthus mildbraedii). The average $\mathrm{C}$ concentration for faster-growing species was about 45\% (Table 4). In 59 Panamanian rainforest species, $C$ content ranged from 42 to 52\% (Martin and Thomas 2011) and 37-44\% for 24 species in Europe (Poorter and Bergkotte 1992). Carbon concentrations are often assumed to be about $50 \%$ of the dry mass; this value is widely used for below-ground $\mathrm{C}$ estimations (Gibbs and others 2007; Robinson 2007), but will overestimate annual carbon inputs through fine roots.

Nitrogen contents also varied in the fine roots of the 10 species. The highest $\mathrm{N}$ content was determined in Teclea nobilis and Maytenus arbutifolia, which in the former may be due to T. nobilis being a $\mathrm{N}_{2}$-fixing species (Orwa and others 2009). The $\mathrm{N}_{2}$-fixing status of Maytenus arbutifolia is unknown but its leaves have been shown to contain high crude protein levels compared to 18 other species (Shenkute and others 2012). Sixteen \% of the crude protein in the leaves is nitrogen (Levey and others 2000). Interestingly, however, no significant difference in $\mathrm{N}$ contents was found between the faster- and slower-growing species groups (Table 3). This contradicts earlier findings on seedlings (Comas and others 2002) that $\mathrm{N}$ concentrations are higher in faster-growing species. Root $\mathrm{C}$ to $\mathrm{N}$ ratios also played an important role in predicting patterns of root decay, and these ratios are a valuable predictive tool in numerous studies of litter decomposition at local, regional, and global scales (Silver and Miya 2001; Leppälammi-Kujansuu and others 2014; García-Palacios and others 2016). The C to N ratios of roots in our study ranged from 26 to 40 , but with no difference between growth rates. This range can be regarded as intermediate values (Reshi and Tyub 2007). Theoretically, the optimum C to $\mathrm{N}$ ratio for microbial growth, and thus decomposition, is approximately 25, but fungi and bacteria can decompose substrates with much higher ratios (Reshi and Tyub 2007). Litter with such C to $\mathrm{N}$ ratio decomposes quickly but $\mathrm{N}$ mineralization is often reduced by increased microbial immobilization as well as protein complexation by polyphenols when the cells lyse (Silver and Miya 2001). Roots with $\mathrm{C}$ to $\mathrm{N}$ ratios exceeding 75 are often much more difficult to break down (Swift and others 1979) due to greater amounts of structural woody materials (Silver and Miya 2001).

The biochemical compositions of roots such as AIF, ASF, and SE vary with species, and these variations determine the root litter quality and the quality of $\mathrm{C}$ input into soil (Xia and others 2015). In the present study, the AIF ranged from 43 to $51 \%$ (combined mean of 47\%; Table 2) and was consistently the highest $\mathrm{C}$ fraction. This value is consistent with other studies, whose AIF averaged 49\% (Hendricks and others 2000) and 50\% (Muller and others 1989). A recent study by Xia and others (2015) also reported that fine roots contained a 2.9fold higher AIF content compared to the other fractions. Abiven and others (2005) also noticed large lignin-like fractions in roots of crop plants. The AIF is primarily composed of highly reduced compounds such as suberin, cutin, and tanninprotein complexes associated with lignin (Hendricks and others 2000; Sun and others 2013). These compounds are thought to be highly resistant to biochemical degradation (Lorenz and others 2007; Sun and others 2013; Xia and others 2015). The AIF was positively correlated with $\mathrm{C}$ content $\left(r^{2}=0.87, \quad p<0.001 ; \quad\right.$ Figure $\left.2 \mathrm{C}\right)$ and RTD $\left(r^{2}=0.84 ; p<0.001\right.$; Figure 2D) and, thus, this relationship may provide some insight into carbon investment to fine roots. In our study, roots with a high lignin content tend to invest more carbon per unit biomass. This can be explained by the higher glucose investment (Table 4) and the higher $\mathrm{C}$ content within lignin (62\% C; Jin and others 2013) compared to cellulose $(44 \% \mathrm{C}$; Chen 2014$)$. The lignocellulose index, a ratio of AIF to the cell wall fraction (AIF + ASF), is higher in slower-growing species, as is the total $\mathrm{C}$ content (Table 3). This suggests that both chemical (AIF) and morphological (higher RTD) factors make the fine roots of slower-growing species more expensive to construct in terms of $\mathrm{C}$ per unit mass. These parameters (AIF, lignocellulose index, RTD) determine the decomposition dynamics (Sun and others 2013; Zhang and Wang 2015) and are good indicators for root substrate quality (Hendricks and others 2000; Prieto and others 2016).

In contrast to the AIF, the amounts of polar extractives (PE) and solvent extractives (SE) were greater in faster-growing species. Solvent extractives are compounds of nonstructural substances, mostly low-molecular-mass compounds (Pettersen 1984; Yang and Jaakkola 2011; Sun and others 2013). Among the individual species, Podocarpus falcatus had the highest extractive fraction (25\%), Apodytes dimidiata the lowest value $(7 \%)$. Both Podocarpus falcatus and Apodytes dimidiata are from the faster-growing species category (Table 2). In an investigation of 14 species from Gelawdios forest for other chemical fractions, Podocarpus falcatus had the greatest concentration of total phenols and condensed tannins in both roots (Tigabu 2016) and leaves (Habteyohannes 2016). Tannins are classified as hydrolyzable tannins (esters of a sugar re- 
sidues (usually D-glucose) with one or more polyphenol carboxylic acids) and condensed tannins (polymers of flavonoids consisting mainly of 3-8 flavonoid units) and are categorized as extractives (Yang and Jaakkola 2011). Some tannins, however, form a tannin-protein complex associated with the AIF that cannot be extracted using neutral solvents (Sun and others 2013). Moreover, Podocarpus falcatus is known to produce and store terpenoid resin, and phenolic resin, mainly induced by injury (Langenheim 2003). Nonetheless, the family has not been analysed chemically in detail and needs further investigation. Pettersen (1984) suggested that solvent extractive materials constitute $4-10 \%$ of the dry weight of wood of species in temperate climates and that the values may be as much as $20 \%$ of the wood of tropical species. Preston and others (2000), however, reported that nonpolar extractives and water-soluble extractives together make up 40$50 \%$ of total dry litter mass in 37 species of trees in Canadian forests. Since extractives are soluble in neutral solvents and do not contribute to the cell wall structure (Pettersen 1984), they are considered as labile compounds that degrade easily compared to other fractions. Sun and others (2013) confirmed that the extractives disappeared rapidly at the initial stages of decomposition.

Cellulose is the Earth's most abundant organic polymer, usually accounting for $35-50 \%$ of dry weight (Chen 2014). In most conditions, the cellulose is wrapped in hemicellulose, which itself accounts for $20-35 \%$ dry matter (Chen 2014). In our study, the ASF that contains mainly cellulose and hemicellulose showed no variation between functional groups, but variation existed between individual species. Among the ten studied species, Podocarpus falcatus showed the least ASF $(30 \%)$, Apodytes dimidiata the highest fraction $(47 \%)$. Tigabu (2016) also found high concentrations of cellulose and hemicellulose $(41 \%)$ in fine roots of Apodytes dimidiata. Due to the chemical bonding and C content (44\% in cellulose), ASF is the second fastest decomposing fraction after the solvent extractives (Sun and others 2013).

\section{Conclusion}

The morphological parameters of fine roots are quite variable among ten tropical species, but reflect the general difference between faster- and slower-growing species. Generally, faster-growing species have higher SRA and SRL but lower RTD, which are characteristics assumed to support high rates of nutrient acquisition but a shorter root lifespan. Our results provide evidence that RTD is positively correlated with AIF, C content, and C construction cost and is consistently higher in slower-growing species. The extractive fractions and ASF of fine roots appeared to be unrelated to any root morphological characteristics. Differences in morphological parameters of fine roots in fasterand slower-growing species reflect the ecological strategy they employ. Overall, our result demonstrates that root chemistry and morphology differed among species as well as between growth rates that determine the decomposition dynamics and $\mathrm{C}$ deposition in the soil. In general, faster-growing species contributed more labile carbon compounds to the soil than slower-growing species, which resulted from lower RTD and low structural components (that is, lignin).

\section{ACKNOWLEDGEMENTS}

Open access funding provided by University of Natural Resources and Life Sciences Vienna (BOKU). This work was carried out within the project "Carbon storage and soil biodiversity in forest landscapes in Ethiopia: Knowledge base and participatory management (Carbo-part)" and was funded by the Austrian Ministry of Agriculture, Forestry, Environment, and Water Management under Grant Agreement Number "BMLFUW-UW.1.3.2/0122-V/ 4/2013". We are grateful to Sebsebe Demissew, National Herbarium at Addis Ababa University, for supporting species identification.

\section{OPEN ACCESS}

This article is distributed under the terms of the Creative Commons Attribution 4.0 International License (http://creativecommons.org/licenses/by/ 4.0/), which permits unrestricted use, distribution, and reproduction in any medium, provided you give appropriate credit to the original author(s) and the source, provide a link to the Creative Commons license, and indicate if changes were made.

\section{REFERENCES}

Abiven S, Recous S, Reyes V, Oliver R. 2005. Mineralisation of C and $\mathrm{N}$ from root, stem and leaf residues in soil and role of their biochemical quality. Biol Fertil Soils 42:119-28.

Aerts R, Van Overtveld K, November E, Wassie A, Abiyu A, Demissew S, Daye DD, Giday K, Haile M, TewoldeBerhan S. 2016. Conservation of the Ethiopian church forests: threats, opportunities and implications for their management. Sci Total Environ 551:404-14.

Baddeley JA, Watson CA. 2005. Influences of root diameter, tree age, soil depth and season on fine root survivorship in Prunus avium. Plant Soil 276:15-22. 
Basile B, Bryla DR, Salsman ML, Marsal J, Cirillo C, Johnson RS, DeJong TM. 2007. Growth patterns and morphology of fine roots of size-controlling and invigorating peach rootstocks. Tree Physiol 27:231-41.

Bekele TA. 2007. Useful trees and shrubs of Ethiopia: identification, propagation and management for 17 agroclimatic zones. In: Tengnäs B, Kelbesa E, Demissew S, Maundu P, Eds. Nairobi, Kenya: RELMA in ICRAF Project, World Agroforestry Centre, Eastern Africa Region.

Birouste M, Zamora-Ledezma E, Bossard C, Pérez-Ramos IM, Roumet C. 2014. Measurement of fine root tissue density: a comparison of three methods reveals the potential of root dry matter content. Plant Soil 374:299-313.

Chen H. 2014. Chemical composition and structure of natural lignocellulose. In: Chen H, Ed. Biotechnology of lignocellulose. Dordrecht: Springer Netherlands. pp 25-71.

Collins CG, Wright SJ, Wurzburger N. 2016. Root and leaf traits reflect distinct resource acquisition strategies in tropical lianas and trees. Oecologia 180:1037-47.

Comas L, Bouma T, Eissenstat D. 2002. Linking root traits to potential growth rate in six temperate tree species. Oecologia 132:34-43.

Comas LH, Eissenstat DM. 2004. Linking fine root traits to maximum potential growth rate among 11 mature temperate tree species. Funct Ecol 18:388-97.

Couteaux M-M, Bottner P, Berg B. 1995. Litter decomposition, climate and liter quality. Trends Ecol Evolut 10:63-6.

Fichtl R, Adi A. 1994. Honeybee flora of Ethiopia. Weikersheim: Margraf Verlag.

Fransen B, Blijjenberg J, De Kroon H. 1999. Root morphological and physiological plasticity of perennial grass species and the exploitation of spatial and temporal heterogeneous nutrient patches. Plant Soil 21 1:179-89.

Freschet GT, Cornwell WK, Wardle DA, Elumeeva TG, Liu W, Jackson BG, Onipchenko VG, Soudzilovskaia NA, Tao J, Cornelissen JHC. 2013. Linking litter decomposition of aboveand below-ground organs to plant-soil feedbacks worldwide. Austin A, editor. J Ecol 101:943-52.

García-Palacios P, Prieto I, Ourcival J-M, Hättenschwiler S. 2016. Disentangling the Litter Quality and Soil Microbial Contribution to Leaf and Fine Root Litter Decomposition Responses to Reduced Rainfall. Ecosystems 19:490-503.

Gibbs HK, Brown S, Niles JO, Foley JA. 2007. Monitoring and estimating tropical forest carbon stocks: making REDD a reality. Environ Res Lett 2:45023.

Gilbert KJ, Fahey TJ, Maerz JC, Sherman RE, Bohlen P, Dombroskie JJ, Groffman PM, Yavitt JB. 2014. Exploring carbon flow through the root channel in a temperate forest soil food web. Soil Biol Biochem 76:45-52.

Gratani L. 2014. Plant Phenotypic Plasticity in Response to Environmental Factors. Advances in Botany 2104:17.

Gu J, Xu Y, Dong X, Wang H, Wang Z. 2014. Root diameter variations explained by anatomy and phylogeny of 50 tropical and temperate tree species. Tree Physiol 34:415-25.

Habteyohannes L. 2016. Leaf traits of church forest trees in north west Ethiopia, University of Natural Resources and Life Sciences.

Hedberg I. 2003. Flora of Ethiopia and Eritrea Pt. 1. Apiaceae to Dipsacaceae.

Hendricks JJ, Aber JD, Nadelhoffer KJ, Hallett RD. 2000. Nitrogen Controls on Fine Root Substrate Quality in Temperate Forest Ecosystems. Ecosystems 3:57-69.
Jin W, Singh K, Zondlo J. 2013. Pyrolysis Kinetics of Physical Components of Wood and Wood-Polymers Using Isoconversion Method. Agriculture 3:12-32.

Katende AB, Birnie A, Tengnäs B. 1995. Useful trees and shrubs for Uganda: identification, propagation, and management for agricultural and pastoral communities. Kampala: Regional Soil Conservation Unit.

Kong D, Ma C, Zhang Q, Li L, Chen X, Zeng H, Guo D. 2014 Leading dimensions in absorptive root trait variation across 96 subtropical forest species. New Phytol 203:863-72.

Kong DL, Wang JJ, Kardol P, Wu HF, Zeng H, Deng XB, Deng Y. 2016. Economic strategies of plant absorptive roots vary with root diameter. Biogeosciences 13:415-24.

Langenheim JH. 2003. Plant resins: chemistry, evolution, ecology, and ethnobotany. Portland: Timber Press.

Leppälammi-Kujansuu J, Aro L, Salemaa M, Hansson K, Kleja DB, Helmisaari H-S. 2014. Fine root longevity and carbon input into soil from below- and aboveground litter in climatically contrasting forests. Forest Ecol Manag 326:79-90.

Levey DJ, Bissell HA, O'Keefe SF. 2000. Conversion of Nitrogen to Protein and Amino Acids in Wild Fruits. J Chem Ecol 26:1749-63.

Lorenz K, Lal R, Preston CM, Nierop KGJ. 2007. Strengthening the soil organic carbon pool by increasing contributions from recalcitrant aliphatic bio(macro)molecules. Geoderma 142:110.

Maeglin RR. 1979. Increment cores: how to collect, handle and use them. Madison, USA: Gen. Tech. Rep. FPL-25. Madison, WI: U.S. Department of Agriculture, Forest Service, Forest Products Laboratory. p 18.

Makita N, Kosugi Y, Dannoura M, Takanashi S, Niiyama K, Kassim AR, Nik AR. 2012. Patterns of root respiration rates and morphological traits in 13 tree species in a tropical forest. Tree Physiol 32:303-12.

Martin AR, Thomas SC. 2011. A reassessment of carbon content in tropical trees. PLoS One 6:e23533.

McCormack ML, Adams TS, Smithwick EAH, Eissenstat DM. 2012. Predicting fine root lifespan from plant functional traits in temperate trees. New Phytol 195:823-31.

Meinen C, Hertel D, Leuschner C. 2009. Biomass and morphology of fine roots in temperate broad-leaved forests differing in tree species diversity: is there evidence of belowground overyielding? Oecologia 161:99-111.

Muller RN, Kalisz PJ, Luken JO. 1989. Fine root production of astringent phenolics. Oecologia 79:563-5.

Orwa MA, Kindt, R J, Anthony RSC. 2009. Agroforestry Database: a tree reference and selection guide version 4.0. 15:5. http://www.worldagroforestry.org/sites/treedbs/treedatabases. asp. Accessed 09 June 2017.

Ostonen I, Püttsepp Ü, Biel C, Alberton O, Bakker MR, Lõhmus K, Majdi H, Metcalfe D, Olsthoorn AFM, Pronk A, Vanguelova E, Weih M, Brunner I. 2007. Specific root length as an indicator of environmental change. Plant Biosyst 141:426-42.

Ostonen I, Rosenvald K, Helmisaari H-S, Godbold D, Parts K, Uri V, Lõhmus K, Rewald B, Nabais C. 2013. Morphological plasticity of ectomycorrhizal short roots in Betula sp and Picea abies forests across climate and forest succession gradients: its role in changing environments. Front Microbiol 4:1-10.

Peel MC, Finlayson BL, McMahon TA. 2007. Updated world map of the Köppen-Geiger climate classification. Hydrol Earth Syst Sci 4:439-73. 
Pettersen RC. 1984. The chemical compostition of wood. In: Rowell R, Ed. The chemistry of solid wood. Washington, DC: American Chemical Society. pp 57-126.

Pinno BD, Wilson SD, Steinaker DF, Van Rees KCJ, Mcdonald SA. 2010. Fine root dynamics of trembling aspen in boreal forest and aspen parkland in central Canada. Ann For Sci 67:1-6.

Poorter H. 1994. Construction costs and payback time of biomass: a whole plant perspective. In: Roy J, Garnier E, Eds. A whole plant perspective on carbon-nitrogen interactions. The Hague, The Netherlands: SPB Academic Publishing. pp 11127.

Poorter H, Bergkotte M. 1992. Chemical composition of 24 wild species differing in relative growth rate. Plant Cell Environ 15:221-9.

Poorter H, Pepin S, Rijkers T, De Jong Y, Evans JR, Körner C. 2006. Construction costs, chemical composition and payback time of high-and low-irradiance leaves. J Exp Bot 57:355-71.

Pregitzer KS, DeForest JL, Burton AJ, Allen MF, Ruess RW, Hendrick RL. 2002. Fine root architecture of nine North American trees. Ecol Monogr 72:293-309.

Pregitzer KS, Kubiske ME, Yu CK, Hendrick RL. 1997. Relationships among root branch order, carbon, and nitrogen in four temperate species. Oecologia 111:302-8.

Preston CM, Trofymow JA, the, Working Group the CIDE. 2000. Variability in litter quality and its relationship to litter decay in Canadian forests. Can J Bot 78:1269-87.

Prieto I, Stokes A, Roumet C. 2016. Root functional parameters predict fine root decomposability at the community level. Journal of Ecology 104:725-33.

Tigabu Y. 2016. Investigation of fine root trait differences among woody species and between functional types in church forest of Gelawdios, Amhara region, Ethiopia, University of Natural Resources and Life Sciences.

Rasse DP, Rumpel C, Dignac M-F. 2005. Is soil carbon mostly root carbon? Mechanisms for a specific stabilisation. Plant Soil 269:341-56.

Reshi Z, Tyub S. 2007. Detritus and decomposition in ecosystems. New Delhi: New India Pub. Agency.

Rewald B, Meinen C, Trockenbrodt M, Ephrath JE, Rachmilevitch S. 2012. Root taxa identification in plant mixturescurrent techniques and future challenges. Plant Soil 359:16582.

Rewald B, Rechenmacher A, Godbold DL. 2014. It's complicated: intraroot system variability of respiration and morphological traits in four deciduous tree species. Plant Physiol 166:736-45.

Robinson D. 2007. Implications of a large global root biomass for carbon sink estimates and for soil carbon dynamics. Proc R Soc Lond B Biol Sci 274:2753-9.

Ryan MG, Melillo JM, Ricca A. 1990. A comparison of methods for determining proximate carbon fractions of forest litter. Can J For Res 20:166-71.

Shenkute B, Hassen A, Assafa T, Amen N, Ebro A. 2012. Identification and nutritive value of potential fodder trees and shrubs in the mid rift valley of Ethiopia. J Anim Plant Sci 22:1126-32.
Silver WL, Miya RK. 2001. Global patterns in root decomposition: comparisons of climate and litter quality effects. Oecologia 129:407-19.

Sluiter A, Ruiz R, Scarlata C, Sluiter J, Templeton D. 2005. Determination of extractives in biomass. Colorado: National Renewable Energy Laboratory.

Solly EF, Schöning I, Boch S, Kandeler E, Marhan S, Michalzik B, Müller J, Zscheischler J, Trumbore SE, Schrumpf M. 2014 Factors controlling decomposition rates of fine root litter in temperate forests and grasslands. Plant Soil 382:203-18.

Sorgoná A, Abenavoli MR, Gringeri PG, Cacco G. 2007. Comparing Morphological Plasticity of Root Orders in Slow-and Fast-growing Citrus Rootstocks Supplied with Different Nitrate Levels. Ann Bot 100:1287-96.

Sun T, Mao Z, Han Y. 2013. Slow decomposition of very fine roots and some factors controlling the process: a 4-year experiment in four temperate tree species. Plant Soil 372:44558.

Swift MJ, Michael J, Heal OW, Anderson JM, Jonathan M. 1979. Decomposition in terrestrial ecosystems. Berkeley: University of California Press.

Valverde-Barrantes OJ, Blackwood CB, Kramer-Walter KR, Bellingham PJ, Millar TR, Smissen RD, Richardson SJ, Laughlin DC. 2016. Root traits are multidimensional: specific root length is independent from root tissue density and the plant economic spectrum: commentary on Kramer-Walter et al. (2016). J Ecol 104:1311-13.

Vertregt N, De Vries FWTP. 1987. A rapid method for determining the efficiency of biosynthesis of plant biomass. J Theor Biol 128:109-19.

Vivin P, Castelan-Estrada M, Gaudillere J-P. 2015. Seasonal changes in chemical composition and construction costs of grapevine tissues. VITIS-J Grapevine Res 42:5.

Wang Z, Guo D, Wang X, Gu J, Mei L. 2006. Fine root architecture, morphology, and biomass of different branch orders of two Chinese temperate tree species. Plant Soil 288:155-71.

Wassie A, Sterck FJ, Teketay D, Bongers F. 2009. Tree regeneration in church forests of Ethiopia: effects of microsites and management. Biotropica 41:110-19.

Weemstra M, Mommer L, Visser EJW, van Ruijven J, Kuyper TW, Mohren GMJ, Sterck FJ. 2016. Towards a multidimensional root trait framework: a tree root review. New Phytol 211:1159-69.

Xia M, Talhelm AF, Pregitzer KS. 2015. Fine roots are the dominant source of recalcitrant plant litter in sugar mapledominated northern hardwood forests. New Phytol 208:71526.

Yang G, Jaakkola P. 2011. Wood chemistry and isolation of extractives from wood. Literature study for BIOTULI ProjectSaimaa University of Applied Sciences 10-22.

Zhang X, Wang W. 2015. The decomposition of fine and coarse roots: their global patterns and controlling factors. Sci Rep 5:9940.

Zobel RW, Kinraide TB, Baligar VC. 2007. Fine root diameters can change in response to changes in nutrient concentrations. Plant Soil 297:243-54. 